\title{
Animated Architecture: Maria Luiza Mendez Lins and the Colonial Water Taps of Olinda, Brazil
}

Abstract: An uneasy relation between water contamination and social contamination plays out at the water tap (bica, fonte, chafariz) in Olinda, Brazil. Originally built to provide fresh water for the public and for ships, the taps are set in decoratively carved plaster or stone walls. Architecturally, they are beautiful, even when overgrown, disfigured by road and utility construction, or strewn with waste. Today, bicas are extraneous to centralized water, sewage or drainage infrastructure. Water flows passively from hillside crevices through the simplest of plumbing. Because the water table underlying the city is contaminated, the quality of water emerging from bicas is always subject to question. The politics of bica performance involves partially clad persons drinking and bathing in central areas of public space, where these architectural extensions of dead colonial powers are sometimes dressed illegally in murals and signatures of graffiti artists. Guided by Iza do Amparo, a painter from Olinda, this essay reflects on the connections among water architecture, social marginality, and street art.

\section{Introduction}

\section{A. The Artist and the Ethnographer}

Maria Luiza Mendez Lins, a.k.a. "Iza do Amparo," is a painter whose studio is on Amparo Street, near the top of one of Olinda's seven hills. In the process of becoming my friend and guide, she infected me with her passion for bicas (water taps), the intimate aquatic monuments that adorn Olinda, a colonial city of seven hills, a UNES- 


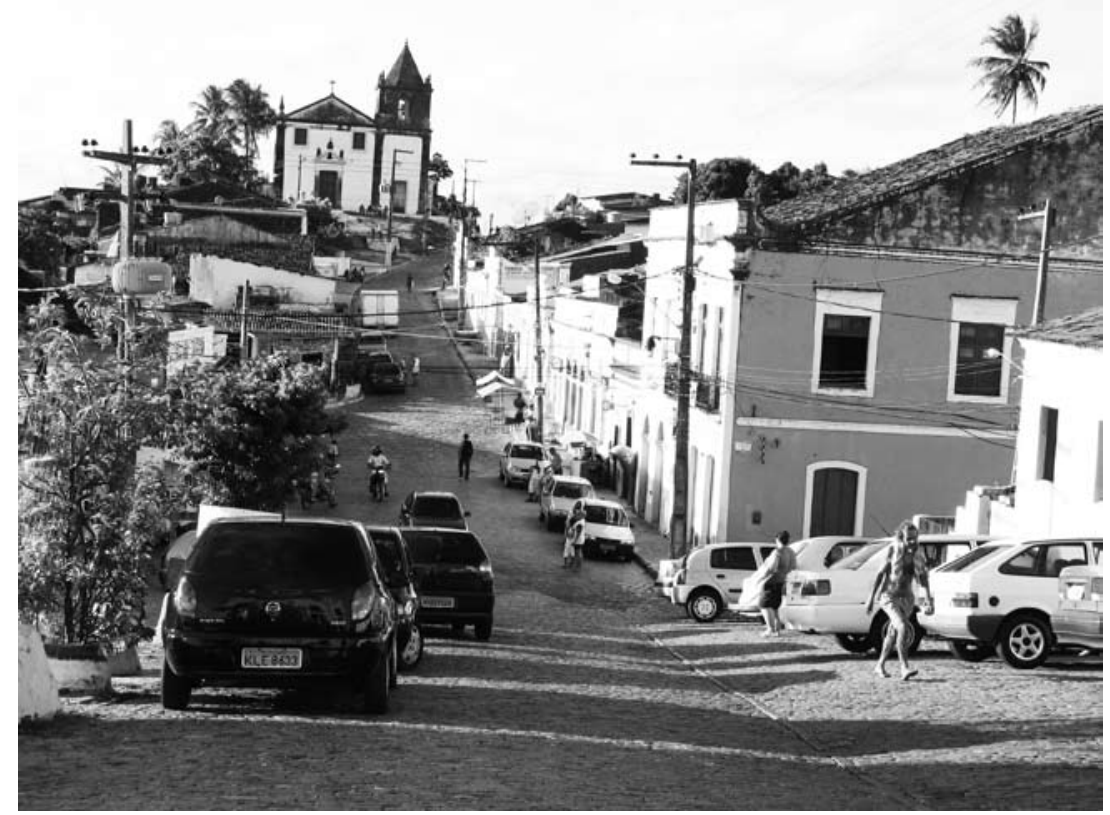

Fig. 1. Amparo Street (Our Lady of Amparo Church on hilltop)

CO World Heritage Site on the northern Atlantic coast of Brazil. ${ }^{1}$ A small big-hearted woman, Iza inspires many others with her knowledge, skills, and creativity. She invented a painting technique that funneled her high culture, art-school training into spontaneous and portable expressions of tropical color and imagery adapted to the tastes of international tourists wandering around Olinda. Her studio doubles as a space for both making and marketing her creations. She paints in a loft from which she can look down onto the gallery. Her studio's large swoops of color and design beckon to passersby through the open top of her turquoise front door. When the door is open, as it usually is, all are welcome to browse, or even to discuss the philosophy of art. Dedicated to community activism, Iza was not content with her own artistic success. She trained generations of younger artists in the skills of painting portable art (e.g., canvas tablecloths, runners, wall hangings, clothes) and in the practicalities of opening a walk-in studio-gallery space like hers. Based on conversations with younger artists, I came to appreciate how her enthusiasm stimulated the evolution of a vibrant artistic scene with studio artists working around almost every corner, nook, and cranny of Olinda's hills. ${ }^{2}$ 


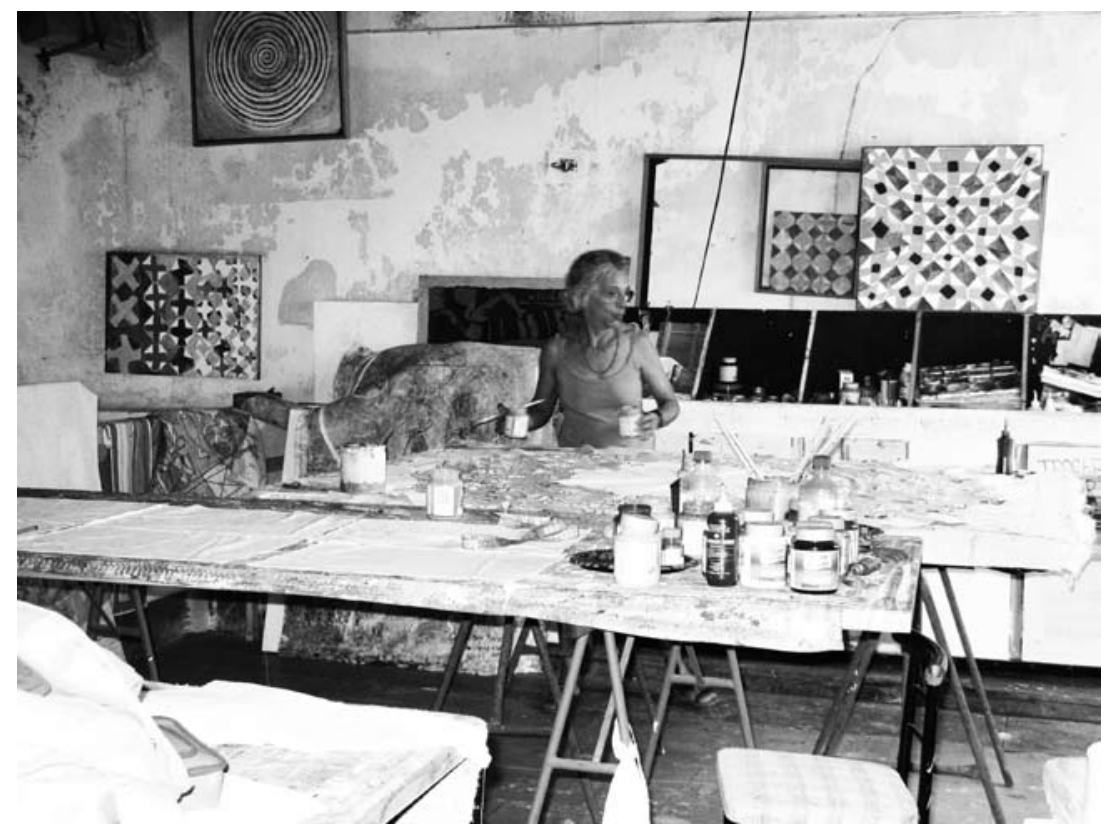

Fig. 2. Iza painting in her studio's loft

On break from a fieldwork stint in Salvador, Bahia, down coast, I looked up Iza on the advice of a mutual friend, London-based Brazilian painter Tania Britto. Iza and I connected on many levels, especially across our occupations as artist and ethnographer. Having studied city planning, Iza developed a practical aesthetics that sees beauty, even as she is dismayed by the crumbling cobblestones that circle the hills. To enhance her own peacefulness in that miniature paradise, she cultivates a lush garden full of fruit trees and medicinal plants, actively maintaining precious green space in the warren of cement and asphalt-prone tourist construction closing in around her. Her aesthetic and training, also, enabled her to understand the dynamic relation between ecology, infrastructure, and the intense human activity that has historically reshaped the crowded hills.

When I explained my water-related research to her, she guessed rightly that I would be attracted to bicas as a distinctive and historical type of aquatic site. I was doing ethnographic fieldwork on urban aquatic ecology and infrastructure along the South American Atlantic coast, focusing on the intersection of fresh and sea water spaces and sources (ocean, beaches, estuaries, rivers) and the engineered ramifications of 


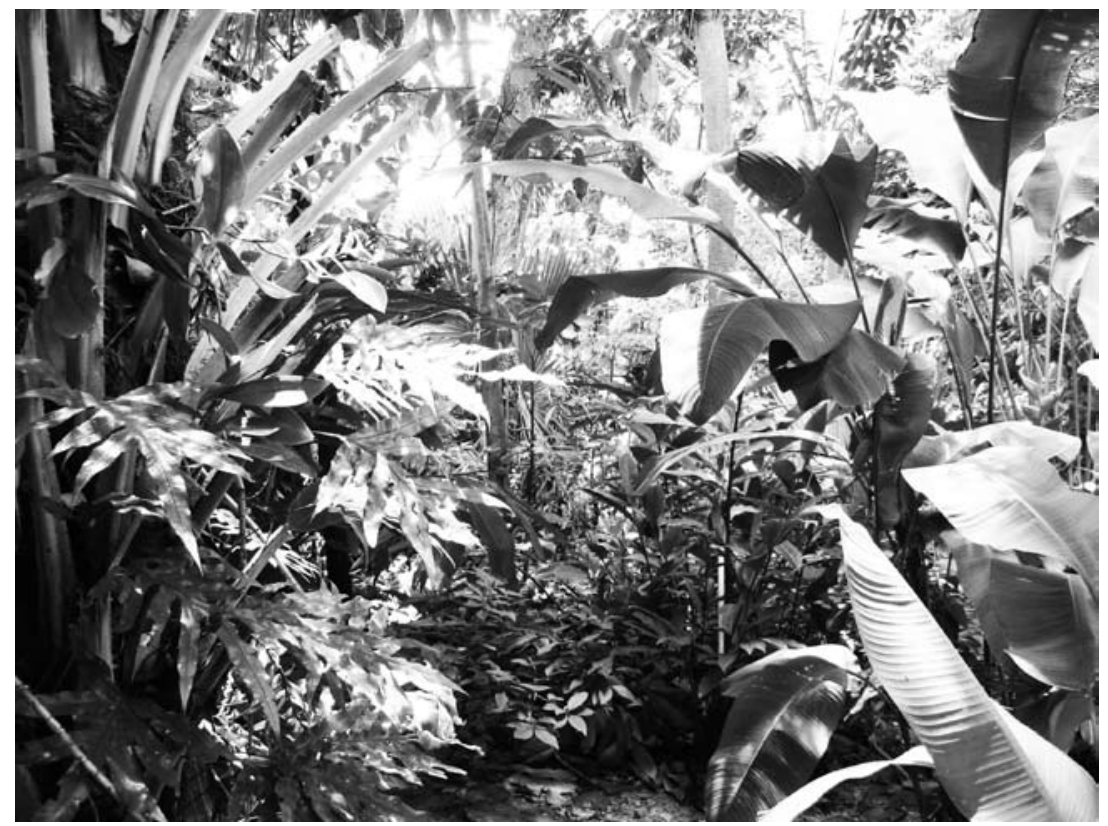

Fig. 3. Iza's quintal (backyard garden)

human effluent flows (pipes, taps, canals, treatment plants). Analyzing the cultural politics of water management, my larger project identifies the organizing logics and expressive modes of inter-related discourses and practices. A pair of questions guides research: How do global forces culturally and materially infiltrate and provoke transformation in local ecological niches? How do local responses manifest and alter those relations? The ethnographic analysis proceeds by way of marginal ecologies, which I define as places and edge spaces forgotten or ignored by centralized administrative and infrastructural networks.

Government regulation and privatization restrain most places and spaces within the central areas of contemporary cities. Marginal ecologies wedge precariously between such regulated spaces. They can be large-scale like the bricolage of favelas (irregular, unregulated settlements or slums) that exist without adequate water and sanitation infrastructure (e.g., Caldeira 2000: 220-24; Kane 2008). Visible aspects of marginal ecologies can also be quite small-scale. As Iza pointed out, anomalous sites like bicas are part of marginal ecologies that underlie and emerge in the very center of the regulated city. Thus, the subject of bicas became the ethnographic focal point of my relationship with 
Iza, the site of playful interdisciplinary exchange and a window into the folklore of this historic Brazilian port.

Our collaboration is grounded in our shared concern for social and environmental justice and our passion for art, architecture, and infrastructure. At the same time, our divergent assessment of graffiti art captures differences in our respective status as insider/artist and visitor/ethnographer. Convergences and divergences within this harmonious ethnographic friendship require an unusual politics of ethnographic writing, one not driven by a need to manage the representation of otherness. Despite our differences in native language, national identity, profession, and connection to place, there is no obvious intellectual breach between ethnographer and informant. We are new friends with mutual interests, rather than the strangers who must bridge the divide of cultural otherness that commonly characterizes ethnographic relationships. Before entering our walking dialogues, I briefly put bicas in historical and ecological context.

\section{B. Contamination and the Bica}

Bicas are an integral part of the original sixteenth-century architectural foundation of Brazilian port cities. Built to provide fresh water to the public and ships, bica taps are embedded in carved plaster or stone walls with drain basins set in front and below; flowing with rainwater, they perch where the crevices of steep hills butt against and open onto planar streets below. In hilly, northeastern coastal cities, bicas are located at intersections of earth's inclines. ${ }^{3}$ Because colonial cities developed around fresh water resources, bicas tended to be centrally located. Some had interconnecting galleries and tunnels underground. In sixteenth- and seventeenth-century Olinda, mapping and naming bicas was a relational, symbolic enterprise used to dominate territory and claim authority and resources. In Sassen's terms, bicas represented a "capability" (2006:6-9), one that enabled globalization in Brazil to benefit priests and traders. Bicas continued to be crucial until the late nineteenth and early twentieth centuries, when networked, potable water systems were constructed. After that, municipal maintenance of these locations for public distribution was not a priority. Today, bicas are extraneous to centralized water, sewage or drainage infrastructure. In contrast to unseen underground water networks of modern urban systems, the frontispieces of bicas are culturally salient points 
of protrusion: water exits the ground through architectural design, often molded with state and church markings. Although clearly a part of infrastructure, bicas appear as small symbolic enclosures set in intimate plazas. Architecturally, they are beautiful, even when overgrown, disfigured by road and utility construction, or strewn with waste.

Water flows passively from hillside crevices through the bica's taps, the simplest of plumbing. Because the water table underlying the city is contaminated, the quality of water emerging from bicas is always subject to question. Indeed, contamination of fresh or sweet water (as opposed to salt water) is almost ubiquitous, especially in urban and industrialized areas. While in the imagination, in language, cognition, and desire, water may be pure, in reality, fresh water is rarely free from chemicals and human waste, only more or less contaminated, more or less subject to industrial water treatment.

Clean, fresh water for drinking, bathing, and admiring represents nature in many cultures and folkways, yet most city dwellers have access to it only through indoor water taps. In other words, in everyday city life, nature does not exist apart from culture or technology. As the contrast between public-access bicas and domestic taps hooked into underground systems reveals, all city-dwellers live in a cyborg world. In this cyborg world, the relatively privileged secure zones and underground networks of industrially cleaned water while the rest are left to fight for inclusion, in the meantime fending for themselves as best they might (Kaika 2005; Swyngedouw 2004). ${ }^{4}$ Thus, commodified water flows from treatment plants into domestic taps, or is pumped into bottles and transported near and far from aquifer, rivers, or other taps. The homeless, poor, and itinerant who cannot access relatively safe water distributed to residences and businesses rely on degraded aquatic resources like bicas, remnants from the public spaces of the past, where available. Nestled between contemporary households, hotels, and restaurants, bica locations have come to occupy an ambiguous material and moral realm, the shared space of an earlier version of "the public good" that now unites colonial architectural style with the pragmatics of poverty. In this context, people use contamination metaphors when speaking about water as substance and site and about graffiti as a form of artistic expression associated with water infrastructure (Kane 2009). This article explores where these connections meet in the space of the bica. ${ }^{5}$ The three walking vignettes that follow suggest the "material conditions, the place-boundedness, and thick social environments" (Sassen 2006:342) 


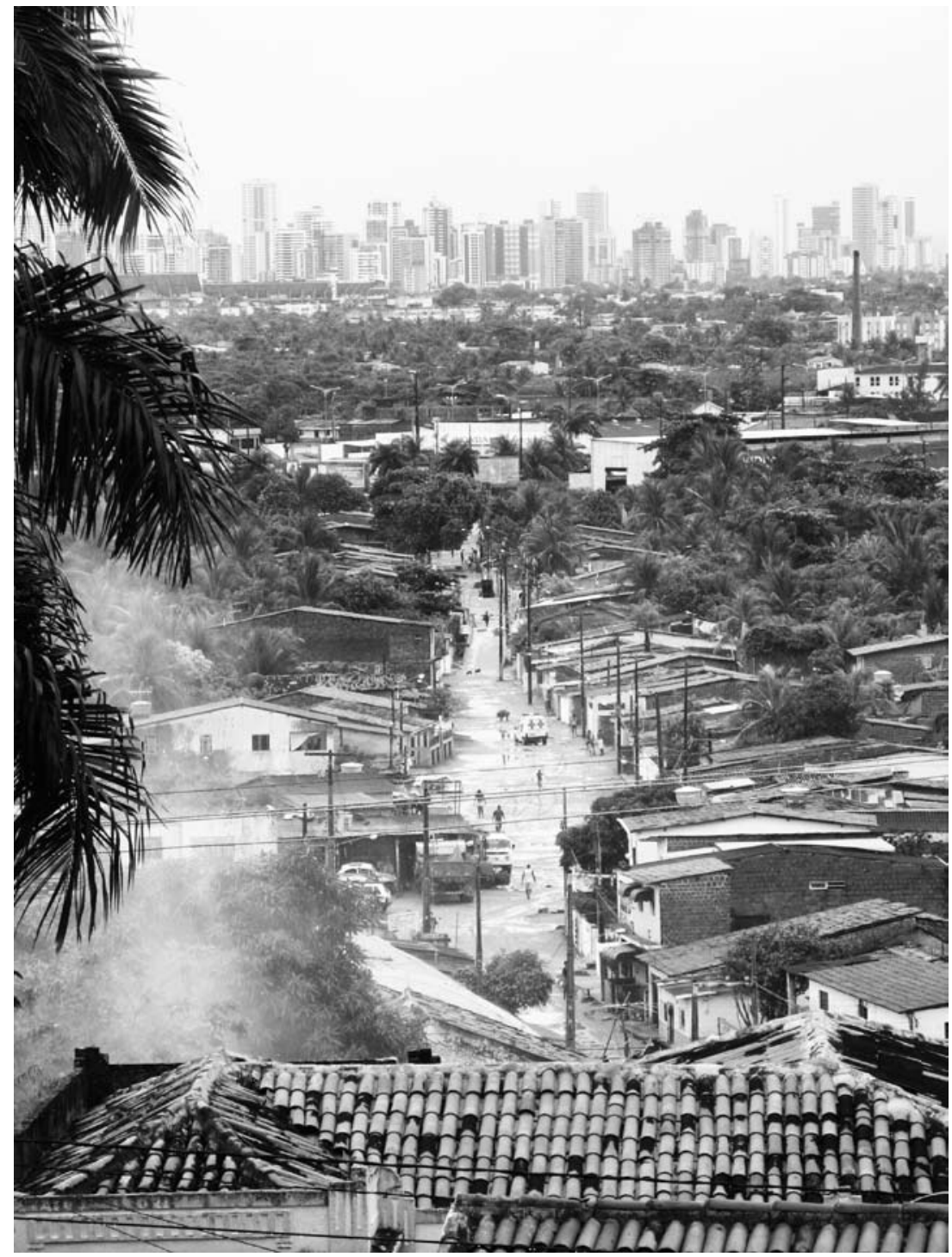

Fig. 4. Varadouro, the favela below Olinda, and Recife skyline

within which three bicas actively survive to this day outside domains of official care-taking.

Each site dramatizes a different way in which water contamination can be used as a metaphor to keep social contamination at bay. At the much-used Bica of the Four Corners, a graffiti mural adorns a water source that functions as bath and toilet, signaling both literal 
and symbolic contamination. In contrast, the residents whose primly painted house sits atop the Bica of Saint Peter reported potential water contamination to the city, which, after testing water quality, shut off the tap, effectively closing down the bica as a social site. The graceful but non-functional Bica of the Rosary and the seeping waste draining down its outflow canal, symbolizes class differences, sovereign territorial relations, and family memories.

\section{Walking Olinda's Hills with Maria Luiza Mendez Lins}

Olinda's beautiful and multifaceted seascape hosts a large, dense, dynamic human population and tourist industry. The built environment is layered into the city's archaic foundation and along the ecologically shifting maritime and riverine edge. The founding colonial churches sit on the hilltops, with hotels, restaurants, and better houses arrayed in descending circles around them. Invasive settlements of rich and poor fill in many of the green spaces, including incursions into the Horto d'El Rei (Orchard of the King), a botanical garden founded in 1798. In the flood zone at the very bottom, a favela receives the water and sewage leaking out of Olinda's elevated but decrepit and incomplete infrastructure, spreading out on the estuarine plane towards the larger city of Recife. We visit bicas in the upper sectors of the hills observing the ambivalent history captured by poets Olímpio Bonald Neto and Mauro Mota in these lines from the Ballad of Amarolinda in the $6^{\text {th }}$ Ballad of the Song of Waters (Cantiga de Amarolinda, Cantiga VI, Canto às Águas, cited in Teixeira 2004:221, my translation).

Bicas doces, milagrosas

Donde beberam os reinóis

E donde os bêbados bebem

E delas fazem urinóis

Bicas sweet, miraculous

Where royalty drank

Where drunks drink

Turning them into urinals 


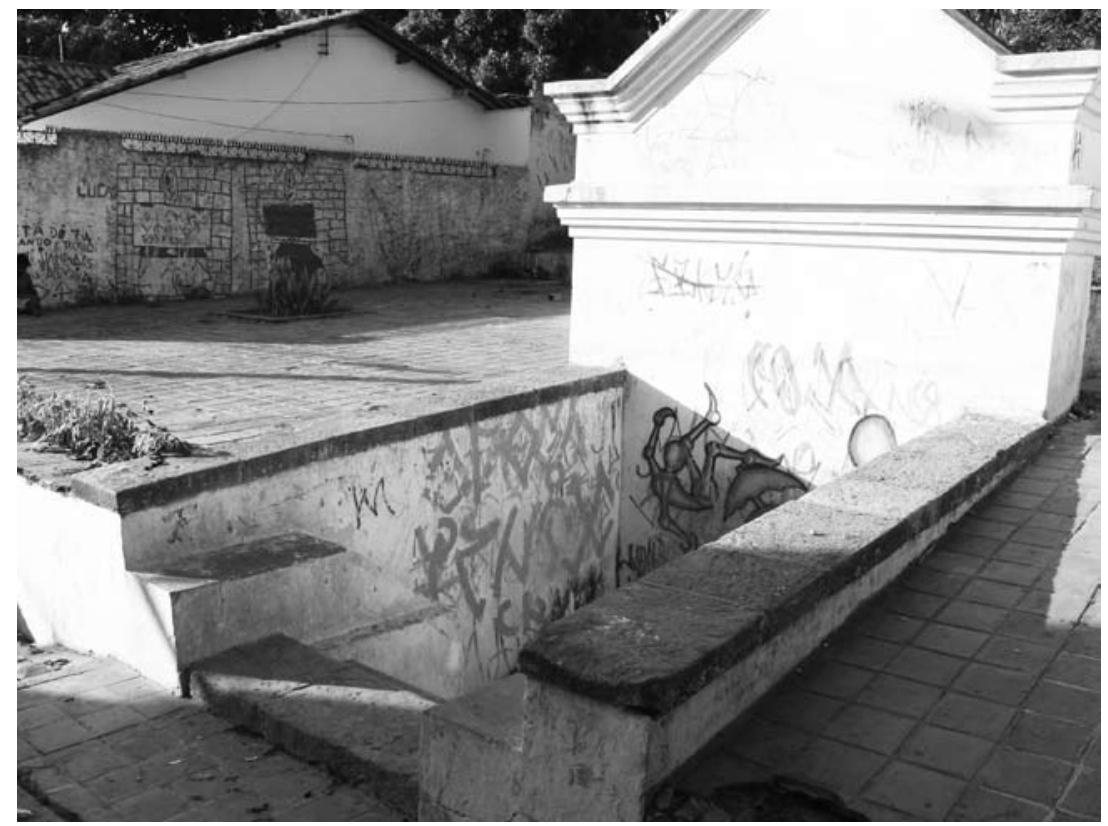

Fig. 5. Bica of Four Corners

\section{A. Graffiti Art and Contamination:}

Bica dos Quatro Cantos (Bica of the Four Corners)

Iza paints contemporary abstract art on stretched canvas for hanging on walls but she is also a master of making totable art (like tablecloths) that economically and culturally sustain the artist community. Along with the best graffiti artists, her colorful improvisations wield spontaneity but do so without defacing architectural heritage. No matter how creative the graffiti on the Four Corners bica, she much prefers to see bica surfaces restored and local creativity redirected. In her view, restoration of colonial water architecture would only enhance the vibrant contemporary art scene, the synchronicity of aesthetic traditions heightening the attraction and entertainment value of Olinda for international tourists. Neither of us would endorse criminalization as a way to approach the problem of graffiti, but for Iza it is fair to say that graffiti is an uneasy fit in her approach to community development. In contrast, for me, graffitoed water architecture and infrastructure provide a curious object of ethnographic contemplation because of the way mundane, taken-for-granted walls are made socially visible 
(Kane 2009). Thus, we approach the first bica with different frames of reference.

The sound of running water enlivens Four Corners, the only one of the three bicas we visit that the city has not shut off. Deposed European hierarchies may haunt its wide stone plaza, but today the site hosts a changeable and lively crew who pay no obeisance to the powers of old and receive precious little benefit from contemporary power-holders. Some contemporary users paint expressive claims onto its carved stone walls; Iza would rather they express themselves elsewhere.

Beyond the plaza surrounding the bica, a path directly passes below the back wall of Iza's garden. Such backyard gardens, with fruit trees, herbs, and flowers, once dominated all the space around the bica's plaza. Now the bica marks the front edge of a narrowing, endangered green space. Iza's neighbors on both sides, and all along Amparo Street, turned their back gardens into rentable guest rooms, restaurants, pools, and hotels with supporting kitchens and laundries; all are hopeful of benefiting from tourists coming to enjoy Carnaval and the works of Olinda's many craftspeople and artists and to see fine examples of colonial architecture. Several neighbors want to convert the largest remaining green space into asphalt parking lots, a move Iza strenuously opposes.

The UNESCO World Heritage website describes how the "harmonious balance between the buildings, gardens, 20 Baroque churches, and numerous small chapels all contribute to Olinda's charm" (2008). Unfortunately, the buildings' harmonious aesthetic balance conflicts with the equally ancient plumbing below ground. Excess water and sewage filter through cracks in the streets and eventually down into the beach and favela. Further spread of asphalt and cement will negatively affect the hydrological balance, which requires the plant-held earthen areas of gardens for filtration. Not only do cement and asphalt crowd out natural niches within the urban fabric, new construction lies atop, and depends upon, the corroding and overloaded potable water, drainage, and sewage systems from the eighteenth and even sixteenth centuries. Existing bicas have survived cataclysms, deterioration, and contamination from sewage since then.

The Bica of Four Corners sits at the intersection of a steep, narrow street named for the bica and the alley that runs behind Iza's quintal. As Iza and I head downhill toward the bica, we see a gathering of four or five middle-aged, obviously intoxicated people. Happy to see her, they gather round. While she chatted with the locals, I photographed 

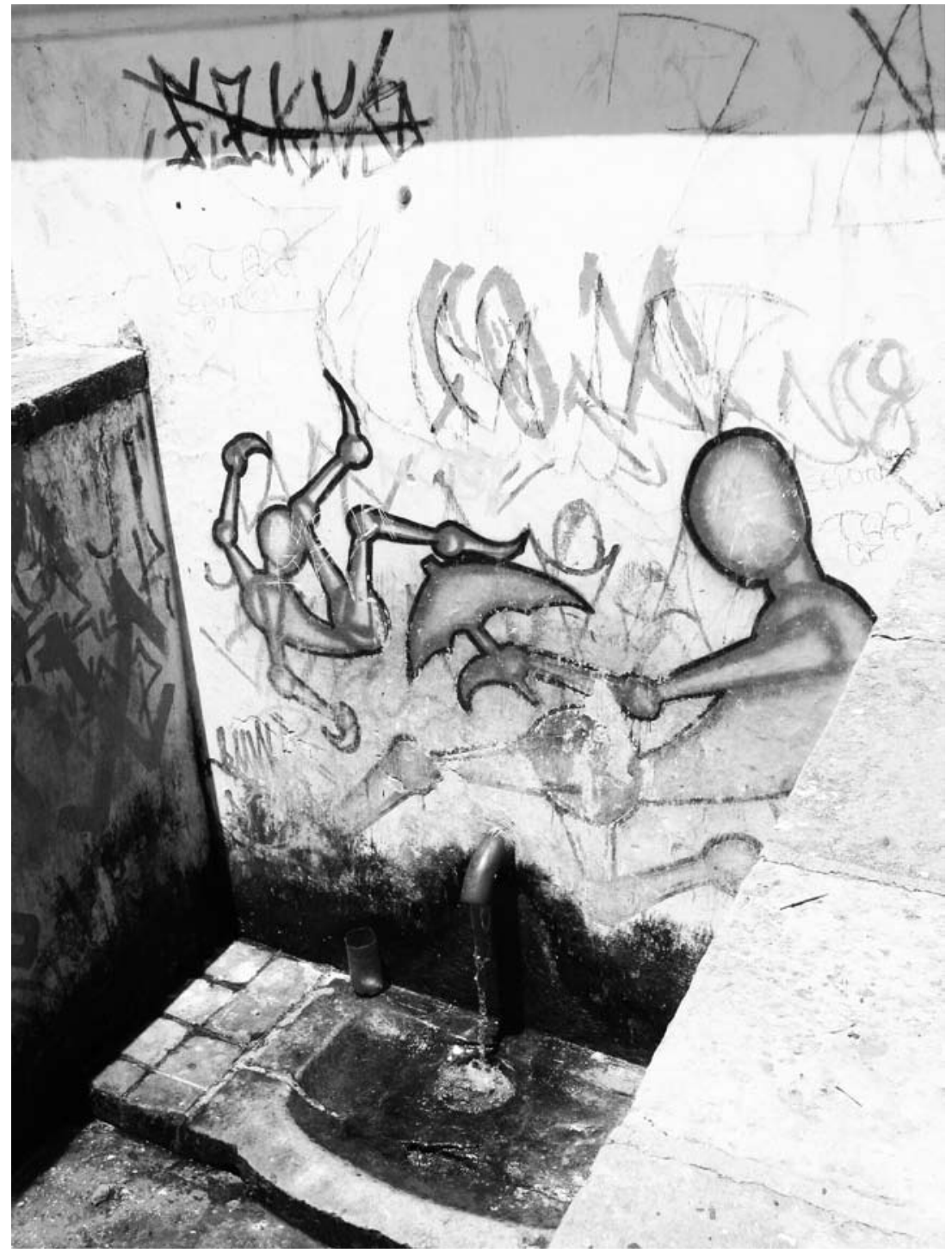

Fig. 6. Graffiti mural and water tap

the painted mural that graced the bica's frontispiece: pink humanoid figures without faces, scythes replacing the extremities of hands and feet, a falling figure and one dancing with an umbrella completed the tableau. ${ }^{6}$ The figures captured my attention, overpowering the tagging (coded variants of handwritten letters) of less talented graffiti writers and painters. A more abstract mural graced the alley wall at the plaza's 


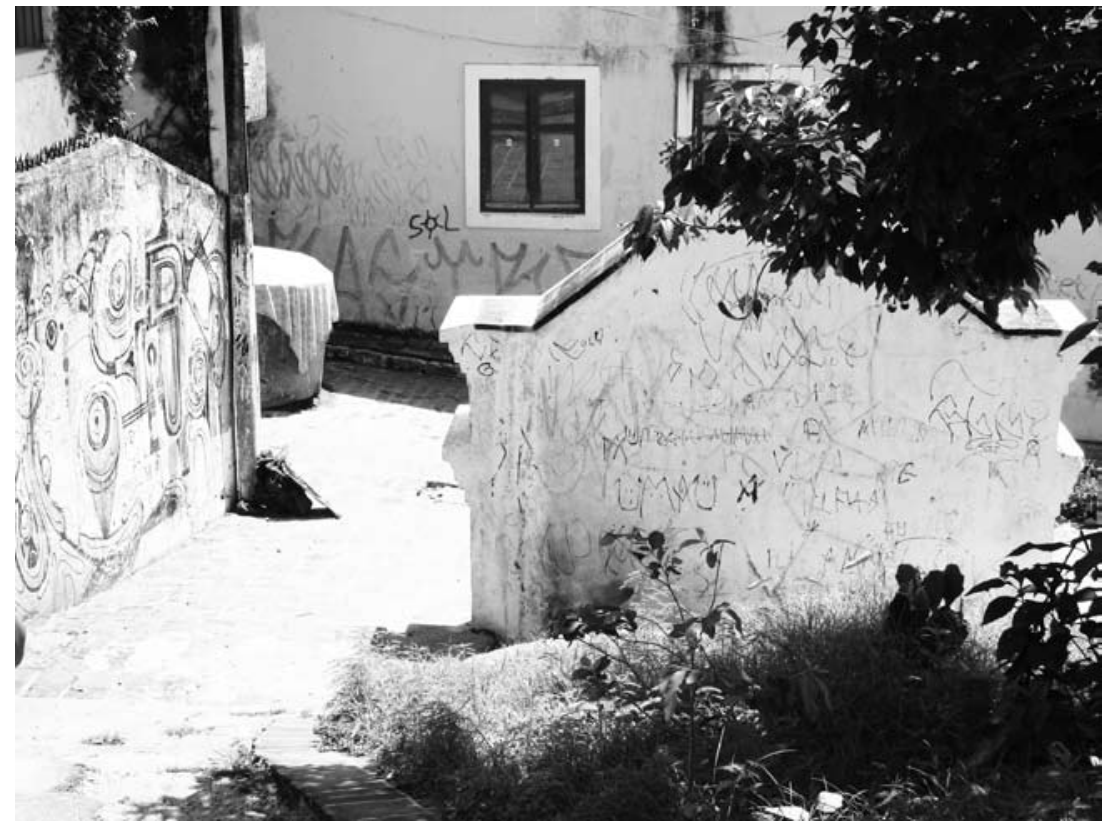

Fig. 7. Graffiti mural on alley (left); back wall of bica (right)

edge. Another day two young ambulantes (walking-traders) washed at the bica. In Figure 7, set beside the wall, you can make out their backpack and velvet-covered panel studded with handcrafted jewelry.

On the backside of the gaily painted frontispiece, excrement and toilet paper dotted the stone floor. People were using the space in front of the wall with the taps as a sink and bath and the space behind the wall as a toilet-not unlike the way people divide the interior of their bathroom into these different functions (minus the flushing toilets). Passersby with access to interior bathrooms most probably respond negatively to the aesthetic and sanitary implications of human waste. (I know I do, even despite my concurrent ethnographic interest in the situation.) After all, hygienists and industrial designers have thoroughly trained city dwellers to prefer cleanliness and privacy (Forty 1992). Unfortunately, the municipality is not up to the task of providing the free, clean, public restrooms as an alternative that would rectify the situation.

Taking these aspects as a whole, the bicas and the surrounding plaza signal deviant mixings of water and excrement, privilege and crime, defacement and art. For Iza, the mural and other graffiti (tags 
and pieces) fit uncomfortably into her concept of art. Although she recognizes degrees of creativity and the impulse for self-expression and identity making, she cannot reconcile these forms with her commitment to seeing the bicas respected and ultimately restored. While such art may well enhance the sense of belonging and social agency of bica users, the deviant mixings at the site create public anxieties that project back onto them (Douglas 1966; Schacter 2008: 42-5; Young 2005:53-5). Deviant mixings of this kind obscure whatever "consecrated capability" this marginal artistic practice may have when it inhabits otherwise unusable remnant spaces (Schacter 2008:42).

In a way, graffiti art is a form of cultural survival that is here inseparable from the chemical and biological substances poisoning water, air, earth, blood: all basic elements of urban existence. Contamination is an inextricable part of the artistic milieu of the living bica, the plaza, and the alley to Iza's garden. In this sense, contamination is both art and anti-art. For some, graffiti art actively opposes the reduction of the bica's meaning to the contamination associated with excrement. For others, the graffiti art symbolically intensifies the experience of contamination. The stakes doubled. On the one hand, policy issues revolve around adequate sanitation and the protection of water sources and architectural heritage. On the other hand, is the question of how city-dwellers and their government representatives draw the battle line between the haves and have-nots.

On various occasions, Iza talked to me about the need to build and maintain clean public restrooms for men and women, to restore the town's treasured bicas, and to invent and subsidize programs to develop and direct the artistic talent toward marketable venues. What follows is a relevant real-world example of her approach, albeit on a smaller-scale.

She and other community members helped to transform the alley that led away from the bica along the back walls of the houses and gardens of Amparo Street, including hers. At one point, a group of architecture students squatted in the alley, built a shelter for gatherings, and hooked up to the city water system, which was fine until a student became overly troublesome and attracted the attention of the police who kicked all the students out. Afterwards, repeated sexual and other assaults troubled the unoccupied alley. Iza and her neighbors reversed the gendered crime problem with a gendered settlement solution: they got together and built a new shelter on the site for a homeless woman 


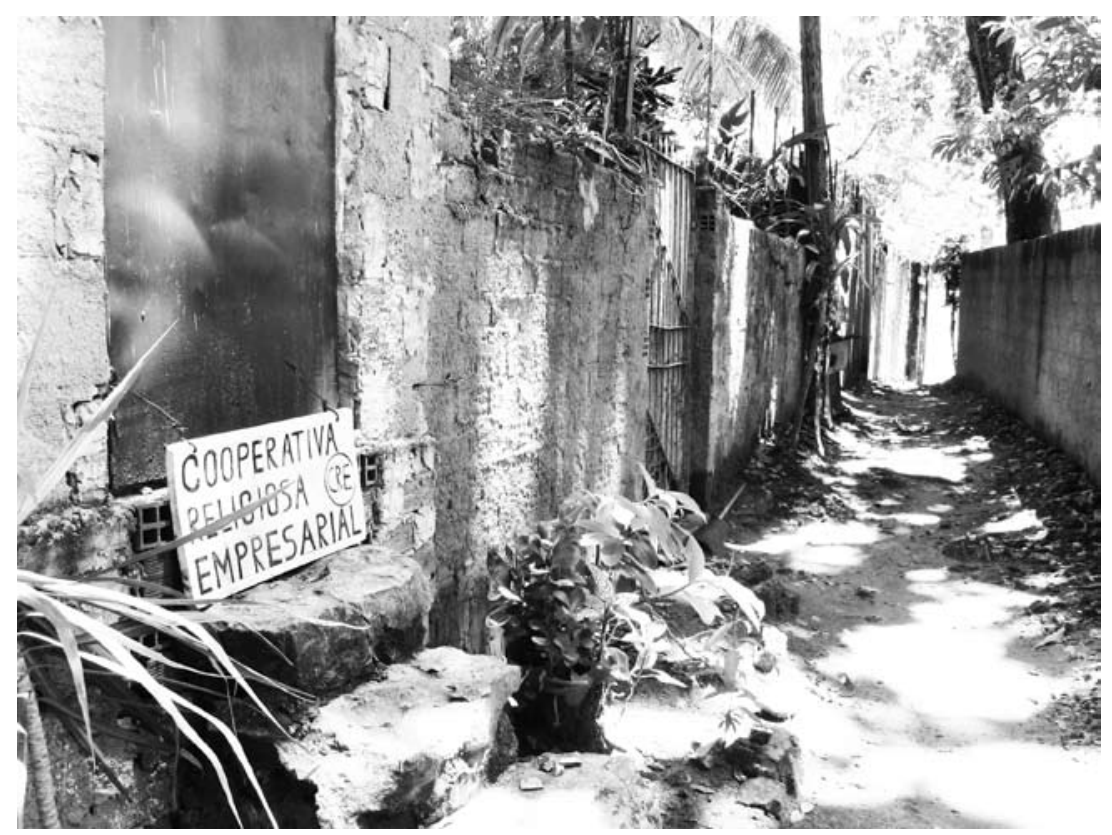

Fig. 8. Alley home of the Mother of Saints with sign for Religious Business Cooperative

who then converted her quarters into a living sculpture of colorful and diverse found materials and images, including ceramic toilets and sinks. She is a Mãe dos Santos (Mother of Saints), a ritual specialist who makes her living as a tailor. An old sewing machine sits atop the alley's entrance in lieu of a sign. I learned this after Iza and I accepted an invitation to visit her. (She was one of the intoxicated people at Four Corners the day that Iza and I first visited the bica.) An altar draped in white lace, upon which stood figures of saints, was prominently displayed among various installations and collages of found images and objects. Its otherworldly grace marked the end of the alley, signifying a spirit-enhancing entry/exit, a magical transfer point that this Mãe dos Santos created for her practice. ${ }^{7}$ Thus, the collective efforts of Iza and her neighbors contributed to the transformation of the alley's use-value toward art, spirituality, social action, and survival. 


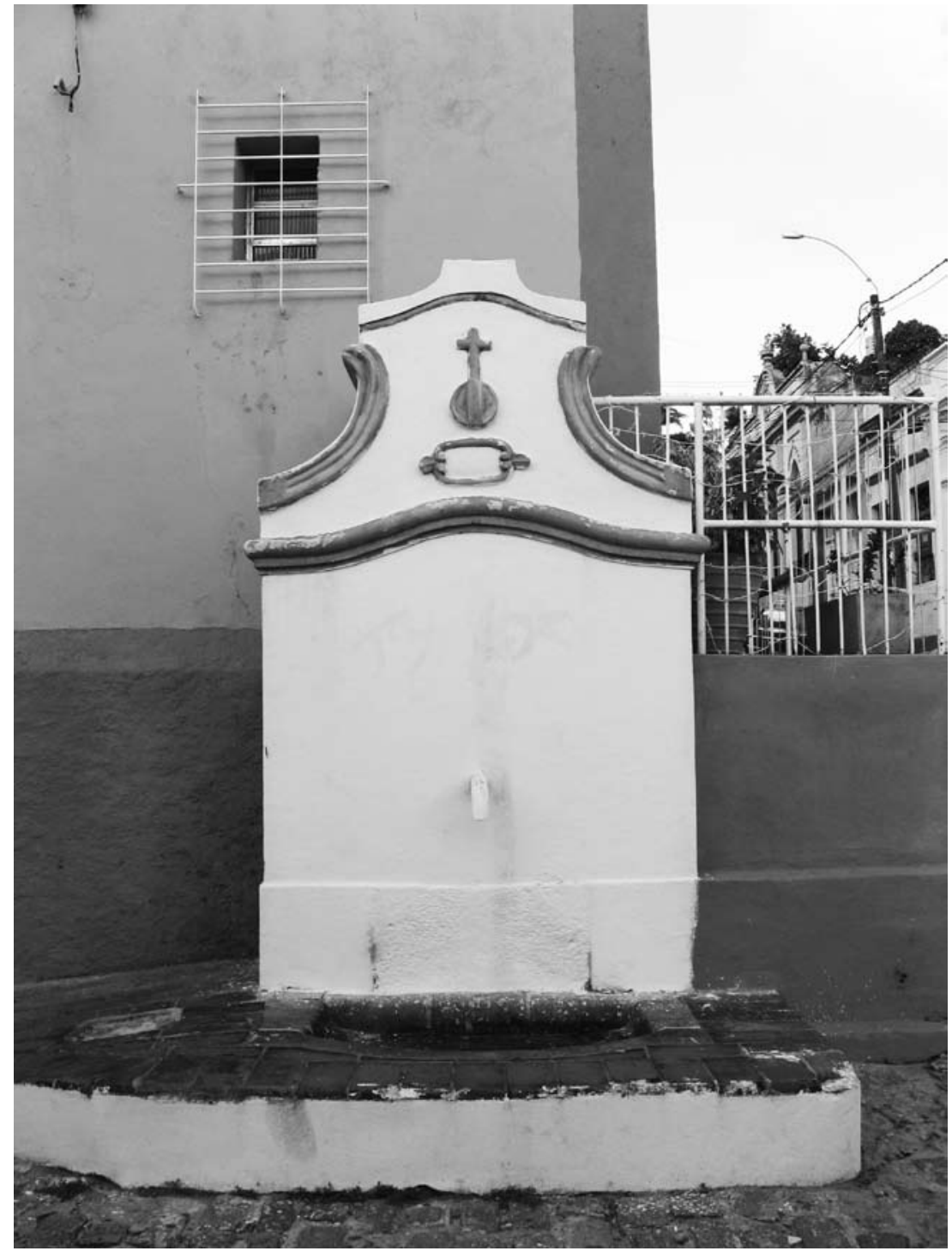

Fig. 9. Bica of Saint Peter

\section{B. Contamination's Alibi}

Bica de São Pedro (Bica of Saint Peter)

Saint Peter's bica is just a few narrow cobblestone streets away from Iza's studio, partway down the steep Enrique Dias Street. Brightly colored, tilted septic-tank lids obscure the fact that the supporting 
cement is crumbling in the too-high water table. The bica sits against a high wall that serves as the foundation of a house. Two residents are sitting on the porch when Iza and I arrive. Neatly painted in white, its trim and emblematic cross in gold, the bica appears in tiptop shape, like the house. Iza tells me that she heard that the residents had the water shut off because they did not want riff-raff hanging about. When I asked them why they turned the bica off, however, they said that it is because sewage is contaminating the water. I could not help wondering if water quality served them as an efficient legal way to have the government get rid of the riff-raff. Perhaps I do not do their motives justice. I nevertheless share Iza's suspicion that water contamination is an alibi, a representation that deploys public health regulation as a mode of social control.

Unlike the bica in nearby Four Corners, a surrounding plaza does not buffer São Pedro from homes that sit atop or around it. The plaza at Four Corners provides users with more ample space. Even so, the unsanitary, graffitoed state of Four Corners surely signals a health and aesthetic threat to the residents of the house atop the nearby bica of São Pedro, if the orderly domestic style of the outside of their house is any indication of their preferences. ${ }^{8}$ Under the circumstances, it is likely that the mixed fear of contamination and deviance triggered the residents' impulse for social control.

However, cutting off access to contaminated water for the users' own protection is only fair if the risk of communicable disease is greater than the risk of living without water. Of course, fairness might not be the most relevant value here. Once the residents brought the law to bear on this situation, it presumably specifies a line that officials cannot cross: too high above the line and they must shut the tap off. Iza and I contemplate how the law and hydraulic technologies might operate in greater fairness to users dependent on the public tap. Perhaps the contamination level is low enough that users might use bleach to sterilize it. Is a filtering system feasible?

Solutions to the bica's social "entanglements" are less apparent." Could the question of social contamination-undesirable users hanging about-be ameliorated by constructing a diversion pipe that would displace gatherings of users from under the porch? Again, a crucial part of a socially just intermediate solution has to include the provision of a set of clean and easily accessible public rest rooms provided by the municipality of Olinda. 
After visiting Saint Peter's bica, we headed downhill so Iza could show me how the high-water table and crumbling infrastructure negatively affected Olinda's Atlantic Ocean beach. Olinda once hosted an active cabotage port, where food and other materials arrived from parts of Brazil and South America but, recently, high seas and a flood left the city with four fewer blocks. The sea flung the huge boulders originally meant for flood protection onto the shore; the resulting pile of rubble demolished clear public access to the beach. Now the once lively neighborhood is derelict; only a few small homes clutch at life. As Iza leads the way, she twirls around in a circle every few minutes on the lookout for banditos. As we pass the closed church, the only sign of life is a bar frequented by soldiers and motorcyclists. By the time we arrive at the beach area most popular with locals for weekend picnics, night approaches. Two streams of sewage trickle down from the road; across the road, giant concrete pipes await construction of new infrastructure.

\section{Contamination's Unstable Hierarchies}

\section{BicA do Rosário (BicA of the RosARY)}

The seventeenth-century Church of Our Lady of the Rosary of Black People of Olinda (Igreja de Nossa Senhora do Rosário dos Homens Pretos de Olinda), built by black slaves for fellow blacks, stands on a small plateau above a field with grass and trees. A handful of men with a radio were there when Iza and I arrived. The field ordinarily serves as a community-gathering place for soccer and relaxation and, during Carnaval, fills with people. Now, however, large piles of earth stand like sentinels next to ditches and giant cement sewage pipes lie on top of muddy mounds, ready for burying. We observed similar scenes on our walks near the beach. Iza said that when workers started digging for the much-needed sewage-extension, they uncovered a barracks foundation, at which point, an archeologist stopped the digging. Although sensitive to the importance of archeological heritage, Iza predicted that the standoff would probably cause a frustrating delay of several years. This is but one small example of an international problem: lack of coordination and internal disorganization among government agencies create obstacles for crucial water infrastructure projects even when already authorized and funded (Caponera 1992). 


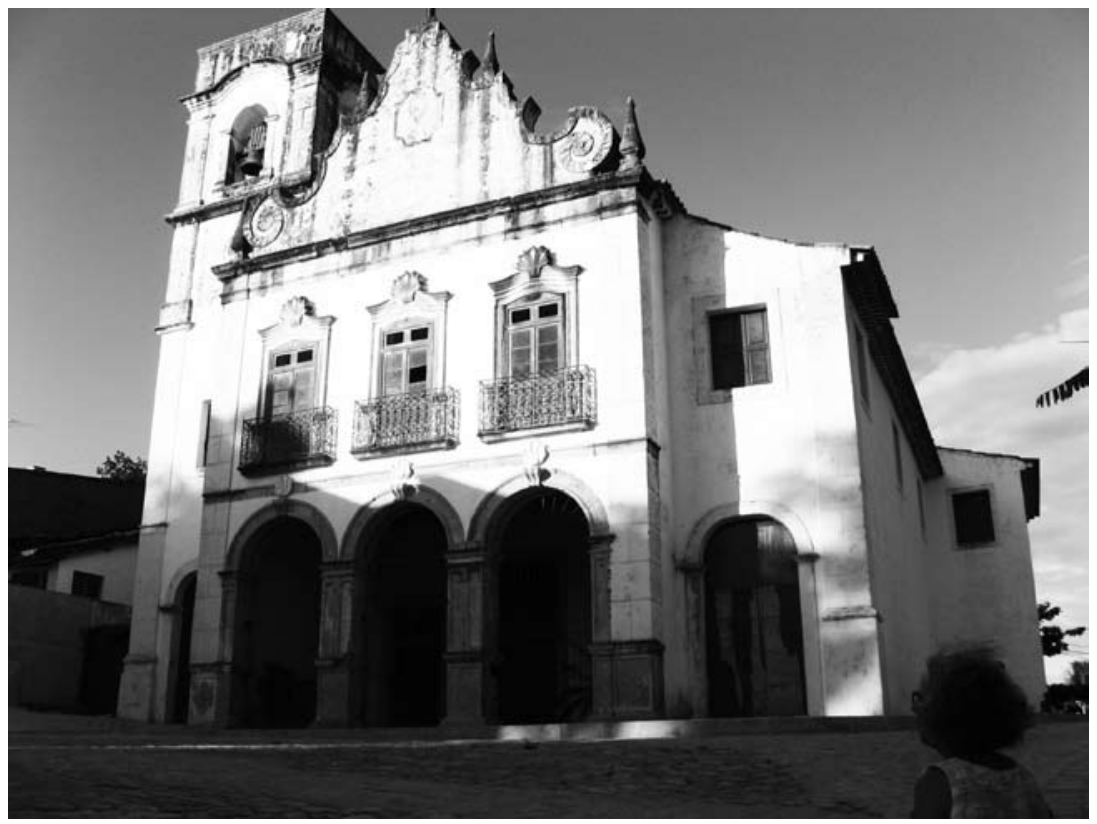

Fig. 10. Our Lady of the Rosary of Black People (with Iza)

Nested in the curve where the field flattens out, the Bica of the Rosary is so overgrown you can only see the curving white frontispiece with its sculpted cross and the top of the basin walls. The wide surrounding stone plaza and staircase are hidden underground, the stone pitchers gone. ${ }^{10}$ Uniquely, this bica has two taps; one carried sweet water and the other (for an unknown reason) carried salt. The sweet came from the church on the hill immediately above us; the salt came from the next higher hill, where the sixteenth-century Church and Monastery of Our Lady of the Mountain (Igreja e Mosteiro de Nossa Senhora do Monte) stands.

The hierarchy between the first, higher sixteenth-century monastery and the later, topographically and socially lower seventeenth-century slave church seems straightforward enough-until we learn that the slaves' church was the source of the more valuable, sweet water. An eighty-six-year-old woman emerged from the adjoining house and orchard when Iza and I rang the bell at the gate. She shared these details with us. She used to pay to keep the bica maintained, she said, but it became too difficult. People threw everything down into it (a tire, even a couch). She had to let it go. She said that the bica opens up into a large underground salon and from thence to tunnels, connecting the church 


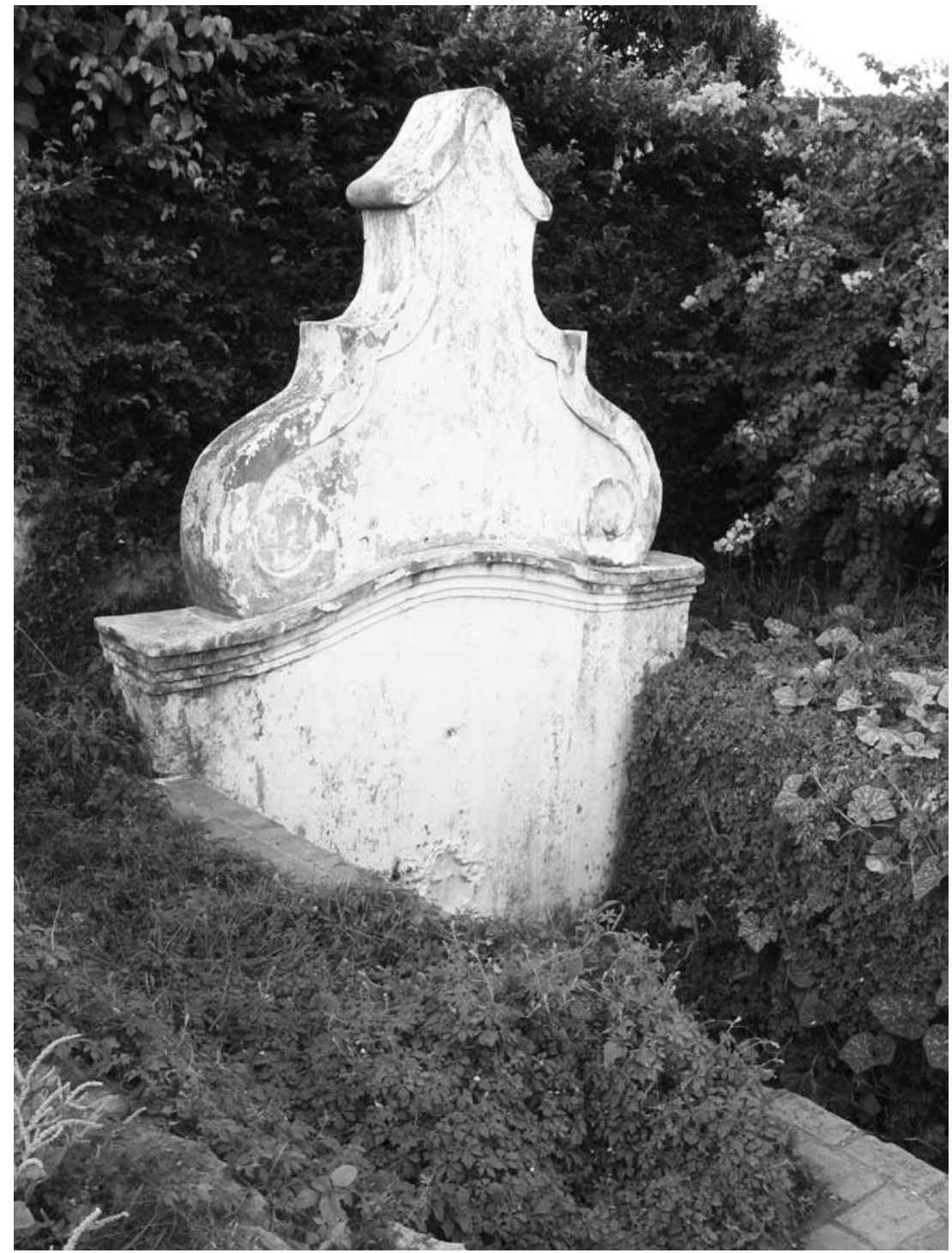

Fig. 11. Bica of the Rosary

on this hill with churches on top of Olinda's other hills. Everyone used to come there to drink water, the old woman noted wistfully.

Later that night, Iza introduced me to a middle-aged sculptor who remembered going to the bica as a young boy to get water for the family breakfast. Not very long ago, he said, a mysterious hazmat team dressed head-to-toe in white protective suits went down into the 
tunnels to explore, came upon a locked brass door, and exited. The sculptor did not know what else the team might have encountered. What was once an ordinary part of everyday life-getting fresh water from the community fountain-has now receded into the past with some sadness and even surreality. One thing the architectural past tells quite clearly: church and state took control of naturally flowing water where it emerged from the hills. Moreover, hierarchical powers took control not only of singular flows but also of territories.

Each bica performs as an aquatic, artistic, and excremental milieu; each yields its own story of use, misuse, social control, and resistance on the 'micro' plane. Yet bicas also actively perform on the 'macro', spatial strategic plane, as continuities and anomalies in the formation of colonial and postcolonial territories (Lefebvre 1991:150-52). Bicas are not unique to port cities. Indeed, they are a common feature of all the towns of sixteenth- to nineteenth-century Latin America. Imagine the performance power of all those persons gathering and socializing at bica sites. As formal elements in a street texture, they introduced repetition and difference, organizing spatiotemporal pathways, conversations, and relationships. They visibly articulated quotidian movement at the heart of the colonial production process.

That afternoon we three women had pondered why people trash the bica. Iza offered that people feel marginalized, as if they do not belong to society. The old woman took exception and said that she came from a poor family of nine children but her parents did not raise her that way. Not all people in poverty feel—or better said, act—marginalized, in the sense of not respecting community norms and resources.

Neither water nor graffiti animates the bica. As on somewhat obscured walls in all public sites, people (men, anyway) urinate behind the bica's frontispiece. An ancient stone drainage ditch is part of the bica's floor plan. ${ }^{11}$ "Look," the old woman points to sewage seeping down along the bottom. Although such oily dark rivulets can be seen draining along many Olinda streets, she identifies those she thinks are directly responsible: "Probably from the landless encampment squatting above in the King's Orchard," she says, referring to the MST, Movimento dos Sem Terra (movement of those without land). She is probably correct, but it is important to situate contamination in a broader class context.

On our architecture and infrastructure walks, Iza showed me how everybody, rich and poor, invades the green spaces. While cities even- 
tually hook up invasions of the rich into centralized water and sewage services, the settlements of the poor commonly remain "irregular," i.e., without sewage services, and less frequently without piped water. We head uphill, passing the encampment, more a temporary affair than concrete favelas. Before the MST came, an Italian man had established a great art school here for local children, but could not keep it going. Since then, MST folk have built small shelters in the clearing beneath the old trees, on the side of the road. Compared to the wall-to-wall cement of middle-class territorial invasions, these settlers appear to have built their shelters with an eye for living in relative peace with nature. As long as you ignore the hard-to-solve problem of sewage seeping down the hill, the scene seems sustainable, respectful. The encampment raises the same moral dilemma one confronts throughout urban Brazil, where bad influences of pollution and poverty intertwine and degrade the aquatic environment. Should the city stringently protect the King's Orchard or allow the homeless a respite? Should it preserve colonial architecture as cultural heritage or permit its use for more basic human need? Wrought in slavery, handed down through generations living unequally in stunningly beautiful waterscapes, the bicas cause the Brazilian people-always with saudades (longing) for the ideal of Brazil-to struggle to resolve diverse variations of this intractable and ubiquitous dilemma. ${ }^{12}$ Iza negotiates the dilemma by pushing for social justice as she engages with the middle- and upper-class decision-makers who hold the city's future in their hands. She encourages the integration of heritage preservation-in the form of gardens, infrastructure and architecture-into urban development plans.

\section{Coda: The Cacimba (cistern):}

Coming down from the Lady of the Mountain monastery, long empty and silent, we sought out the ancient cacimba inside a middle class housing settlement. Iza was determined to locate this last neighborhood example of colonial waterworks in her knowledge base. Skirting the bottom of the hill that is legally a continuation of what should be the King's Orchard reserve, we stand at the entrance to a small, irregular courtyard formed in the space between three small houses. We asked some women who sat on a porch off to one side (playing cards?) for permission to see the ancient cistern. "There," Iza pointed to a barely noticeable square of low remnants of the original stone 
wall. We got close, lifted the cacimba's small, round wooden cover at the center of the square. The women said they used the water for washing, not drinking. Two big turtles floated within the dark water, just like the turtles did in the cisterns of ancient times.

\section{Theoretical Reflections on Nature, Culture, and Colonial Transformation}

These reflections are not based on empirical data but on my desire to use bicas to think through how I might integrate water infrastructure into cultural theory more generally. Of one thing I can be sure, based on my walks and talks with Iza: despite spatial centrality and aesthetic value, bicas today are temporally and socially marginal, remnants of bygone church-state sovereignties. ${ }^{13}$ The once purer streams enabled the advance of colonization and the sustenance of all. Now the sound of water, although it might enchant passersby, provides sustenance only to those who cannot afford interior, private appurtenances for drinking, washing, and bathing. Like sovereigns of old, the wealthy of today have restructured urban space and engineered new, postcolonial forms for controlling water flows and territories (from plumbing to multimodal shipping). Instantiating the architecture of their time, bicas symbolize the colonial past that reaches into the present, a past that continues to unsettle the present (cf. Comaroff and Comaroff 1997:xiv). Their continued relevance to water users highlights the social fact that class privilege limits access to modern centralized water and sewage infrastructure.

In this context, water contamination is not just a physical fact to be variously accepted, scientifically measured, and legally regulated. Contamination acts metaphorically to intensify segregation of rich and poor, to reduce the size and viability of public spaces, even to implicate the poor in the causes of their suffering. For those who have comfortable domestic spaces replete with water-provision and wastewater disposal, an ambivalent dance of valuation may occur, one in which they recognize the bicas' architectural heritage but reject their use and those who use them. Those who need bicas to survive negotiate with that rejection and, in some circumstances, fight for access to these architectural spaces, their aquatic resources, and cultural significance. Graffiti arise out of, or beside, that fight. Its rude 
liveliness is part of, at the same time marginal to, the art scene of Iza of Amparo Street.

In his theory on art and agency, Alfred Gell argues that the places in which art objects are apprehended form part of the artist's and art object's "causal milieu." Out of this causal milieu arises a shared social agency. If contamination is a key condition and metaphor operating in a causal milieu, as it is in the example of bicas and other forms of water provision, how does this shape the performance and politics of social agency? That is, what does it mean when one mode of water distribution, considered safe and reliable, is available to a more privileged majority, and another, viewed as problematic, historicized, dated, and contaminated, is relegated to an impoverished minority? Metaphors of contamination circulate in the negotiations of these questions as they arise in specific situations. Their use at bicas points to the robust metaphorical stream winding through urban water discourses throughout this "planet of slums" (Davis 2006).

In general, cultural frameworks of interpretation and conflicting interests attempt to impose order on material and symbolic sources of contamination (Douglas 1966). Cultural frameworks that impose order on public and private urban space condemn graffiti. Entering into what graffiti writers and artists see as a mutually productive dance, they challenge the forces of order with ever more daring, clever, and at times beautiful expressive wall work (Ferrell 1993, 2001). In her essay, "Written on the Skin of the City," Alison Young finds a strong tendency to speak of ordinary graffiti in the language of bodily waste, dirt, infection or disease. This tendency, she argues, is a defining characteristic of graffiti's "relational," "representational matrix"(2005:51). Given that excrement and its olfactory emanations are likely to be present along the edges and backs of some bicas, how much more palpable must be the tendency to invoke such language.

In any case, illegal graffiti by unofficial artists, molded and painted symbols of an earlier regime, and billboards advertising corporate products all depict forms of graphic art that expand the semiotic range of cultural experience for passersby (Kane 2009)..$^{14}$ In Lefebvre's terms, art and architecture change the "texture of street experience" (1991:132). Using Venice as an example, he finds a dialectical relation between spaces created by human labor and those that (appear to) flow from nature (p. 74): 
it may be said of the space of canals and streets, [that] water and stone create a texture founded on reciprocal reflection. Here everyday life and its functions are coextensive with, and utterly transformed by, a theatricality as sophisticated as it is unsought, a sort of involuntary mise-en-scène. There is even a touch of madness added for good measure.

Olinda's bicas, of water and stone, with underground tunnels and galleries, also have the requisites for theatricality. Do they not manifest an imaginative link between mythically separated realms of nature and culture, visible and invisible (cf. Lévi-Strauss 1967)? They are material transfer points where underground waters become surface waters, where surface pollutants contaminate deep-water aquifers, where colonial history becomes contemporary conundrum, and our chemically chaotic effluvia enter the geological past. The lines of bicas divide and paradoxically assume dimensionality and a sense of place and shape. ${ }^{15}$ Whether colonial powers constructed and marked bicas to enhance the "magic of the state" (Taussig 1997) or whether ordinary, contemporary persons, who live marginal lives, paint figures and landscapes of their imagination on their frontispieces, passersby (at least this passerby) impulsively claim or engage reflexively with points of potential transformation. Bica users leave residues, from paint to excrement, of all their orderly, ecstatic, angry, or merely haphazard activities. Whether generated in the mode of authoritarian rule, spiritual quest or political resistance, the residues suggest that they pertain to some combination of deviant, artistic, and possibly sacred motives. ${ }^{16}$

From the ethnographer's view, these discrete, interstitial spaces animate neighborhood social interaction. Water provides not simply basic "natural" resources, but also the symbolic power through which, and for which, the state and society struggle. Animating the spaces of cultural heritage, water users and mural-painters "both keep and transform the choreographies of meaning" that remnant colonial architecture makes available (Taylor 2003:19-20). They are exemplars of the "ambivalent heritage" of colonialism (cf. Bhaba 1994; Chadha 2006; Chaterjee 1993). ${ }^{17}$ As such, bicas open spaces for ethnographic inquiry about water infrastructure, art, and politics. ${ }^{18}$

Nevertheless, I yield to Iza's insider perspective on the matter of graffiti art on Olinda's bicas. She would prefer, I believe, to bring street artists with talent into the circle of tourist production so that they could make a living while expressing themselves, as many of her apprentices have done. Moreover, restoring bicas to reveal their 
beauty in an unproblematic way, untainted by poverty and deviance, can magnify their social power. For example, restoring the Four Corners bica would weaken the impulse to sacrifice it for a driveway and parking lot to service hotels and restaurants, a plan that circulated among those of Iza's Amparo street neighbors who had commercial interests. A different set of neighbors hoped to use the green space as a children's playground. Thus, a successful fight to protect the bica could effectively save the remaining green space and enhance the lives of children. The bica can only protect the green space if the community respects its beauty and value. The folklorist's impulse to classify, preserve, or encourage at least some forms of graffiti as folk art must be considered within, and the consequences weighed against, the larger social and environmental struggles taking place.

\section{Conclusion}

The slaves, they say, disposed of their rulers' dirty water by spilling it out over the house wall but they left the compound to collect fresh water at bicas. Before germ theory, modern medicine, and twentieth-century sanitation, whenever water-borne diseases like typhoid, cholera, or yellow fever struck, rich and poor died in numbers that were more comparable. Our more advanced and complex twenty-first century version of waterand waste- management has effectively assured the distinction between rich and poor, which, in turn, assured that the poor are more likely to die and the rich more likely to survive.

Bicas sustain people without access to fresh water, the people who depend on the water that flows from the earth, the clear space in front of the tap, even the plastic cup left for passersby. Others, with ownership or official authority, can shut taps off or paint over graffiti-attended surfaces, voiding evidence of unwanted subjectivities even as they protect their would-be-users from microbes. The official, or owner, can banish the micro-social worlds drawn to the flowing energy, spiritual uplift, and material sustenance of springs. Resource destruction is a form of social control, ideologically and legalistically supported by the measurable fact that many points in the water table-the topmost friatic soil layer-have been and continue to be polluted. Thus, the physical and metaphorical reality of water contamination (and its associated sites) can always be suspect and subject to surveillance. Given their redundancy and relative contamination with respect to the main 
treatment and distribution system, it seems miraculous that any bicas have survived. That they have survived, I believe, is a tribute to their architectural beauty.

Merely renovating colonial architectural heritage is not the answer, for as in other sites, cities recreate them as touristic spaces that disinherit those most in need (e.g., Collins 2008). As ethnographer, I must include this ethnological perspective along with Iza's if only because I know that people with Iza's commitment to justice, art, and sustainable urban ecology do not rule Brazilian cities. We need to keep both local and ethnological perspectives in play in our practice and in our writing. The best and most difficult solution, of course, is to begin controlling the sources of contamination (petrochemicals, fertilizers, pesticides, detergents, and garbage) that cities produce and wash down into ground and surface waters, to construct water and sewage services in the irregular settlements, to close poorly constructed wells that contaminate aquifers, and at the least, to build public restrooms. However, following standard attempts to spur economic models of urban development, city planners are more likely to construct decorative replicas, color- coordinated to commodified perfection for European and U.S. currency-holders to spend in spaces that are privatized and policed for the pleasure and protection of tourists. The colonialist aesthetic enjoys a revival in Disneyfied, postcolonial "landscapes of power," trading in provision of basic human needs (cf. Zukin 1991). In Olinda, this process manifests as a shapely woman I saw sun-bathing in a colonial-style hotel garden, occasionally rinsing off in a bica-replica hooked up to city water.

The three relics of aquatic architecture Iza showed me on our walks lead me to think about how the impulse for artistic and architectural agency arises in part from the character of aquatic places. Performances at bicas make visible serious difficulties in the relation between humans and water. In and through everyday performance processes, the metaphor of contamination organizes expression and affect, recasting and responding to the physiochemical properties of pollution with art, alibi, and evidence.

As an artist and neighborhood activist, Iza keeps track of the unstable balance of architectural fixity and cultural and aquatic flows, bringing this ethnographer into their causal milieu. ${ }^{19}$ As artist and ethnographer, we together discover intellectual connection at the bicas of the Four Corners, Saint Peter, and the Rosary, aquatic sites that have remained in place as the world changed around them. Like 


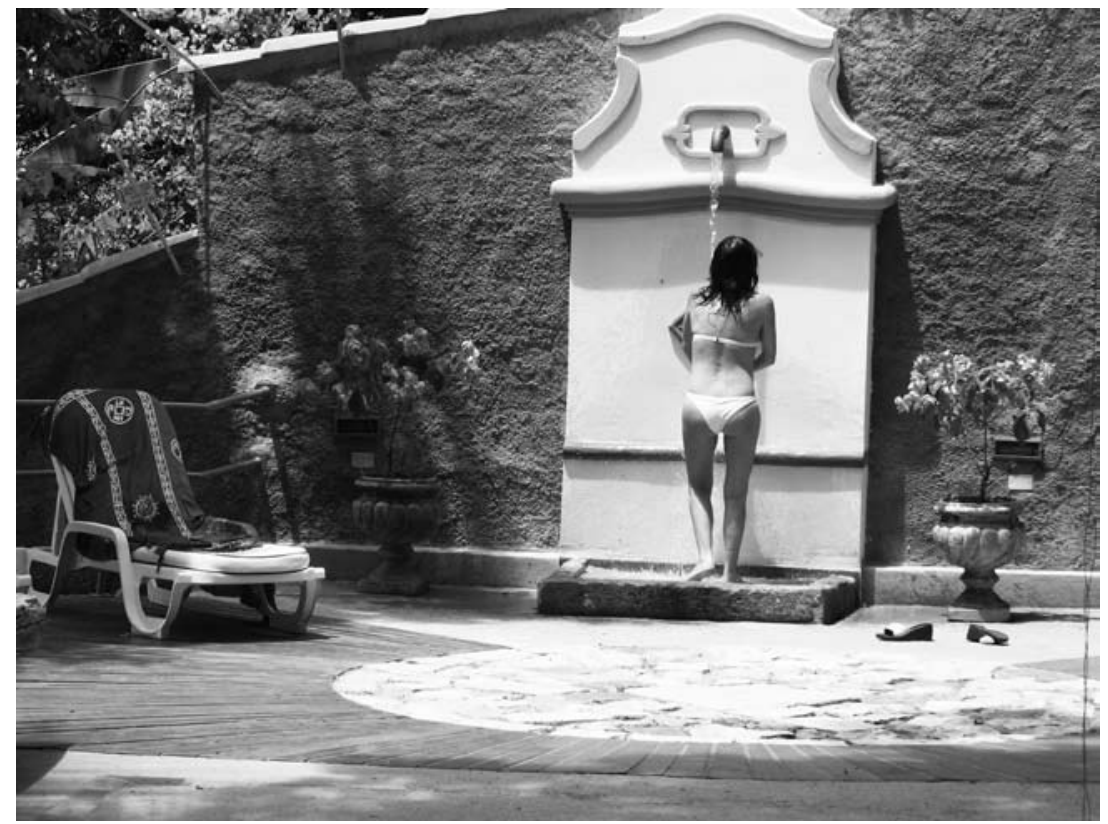

Fig. 12. Hotel guest bathing in treated water from replica of colonial bica

alternative dimensions in Italo Calvino's 1974 Invisible Cities, bicas are memories existing precariously beside current events. As such, they may slip from the notice of officials, developers, and urban narrators. Through the sound of their flowing springs and dissonant visual beauty, bicas exhort action from a distance. Their "symbolic alchemy" (Bourdieu 1998:102) is forged in the contamination that pervades us all, more or less, depending on where we drink.

\section{Indiana University}

Bloomington

\section{Acknowledgments}

Thanks to all the people in Brazil who shared their knowledge and joie de vivre, especially Maria Luiza Mendez Lins, without whose friendship and inspiration bicas would have gone unremarked, and London-based Brazilian painter Tania Britto, who introduced us. Thanks to Anne Brydon and the Department of Anthropology of Wilfrid Laurier University for comments when I presented an earlier version of this work as a keynote lecture, Waterloo, Canada, 28 February 2008. Special thanks to Pauline Greenhill and C. Jason Dotson for their helpful comments and editing. Fulbright Hays funded field research and a sabbatical from Indiana University supported writing. 


\section{Notes}

1. Bica-walking interviews with Maria Luiza Mendez Lins took place on 28 and 29 December 2006 and 2, 3, 4 January 2007. Water taps or fountains are also called fonte and chafariz in Portuguese.

2. I arrived during the Christmas and New Year holidays of 2006-2007, at the beginning of a downturn in Brazilian tourism that accompanied news of violence and the rumblings preceding what was to become the global economic crisis. Olinda's artists had begun to suffer the loss of patrons and customers passing by their open doors.

3. Hydro-geographically speaking, bicas are located where permeable and impermeable layers of earth meet, or where the incline of a valley intercepts the water table (de Lima 2005:14, 17).

4. On gendered politics of water in Latin America, see Bennett et al. 2005; on cultural analysis of bottled water, see Fortun and Fortun 2007; on poststructuralist approaches to nature, see Descola and Pálsson 1996 and Braun and Castree 1998.

5. In general, urban, coastal water infrastructure in Brazil has received little scholarly attention as cultural issue. A notable exception is Gonçalves de Lima's (2005) master's thesis, a hydro-geologic and social study of Salvador da Bahia's bicas. For ethnographic studies of the meaning of water infrastructure and architecture, see Limbert (2001) and Strang (2004).

6. Curiously, I later photographed a mural with a similar humanoid figure in the city of Salvador, in another animated bica, named Fonte de Predreiras ou da Preguiça (Fountain of the Quarry or of the Idle), where water still flowed from multiple taps.

7. I infer the altar's magical transfer capability from my ethnographic research on Emberá and Waunan shamanic practice (Kane 1994; 2004).

8. Meinzen-Dick and Pradhan (2005:246, 253, n 13) point out that references to water quality in religious law of Kathmandu, Nepal, generally refer to ritual purity (e.g., contamination by low castes or the flowing state of water) rather than water's biological or chemical content. I suspect that this ritual sense of water quality is analogous to the cultural dynamics at Bica of Saint Peter. See also Haberman (2006).

9. Mandana Limbert (2001:48) provides a culturally rich analysis of the "entanglements" of water infrastructure and distribution with a multitude of discourses and practices in Oman, including another example where a family's provision of drinking water to passersby provokes intra-family conflict and reveals class tensions.

10. Historical photo and description gives additional details (Teixeira 2004).

11. The bica and drainage ditches should be preserved as archeological heritage from the 1600s. Indeed, plans for renovating the Bica of the Rosary are in process (personal communication, Iza, December 11, 2008).

12. I came across another example, a politically explosive situation, not far outside the port city of Santos. In the legally protected coastal montane forest, an invasive settlement perched on the edge of a river flowing directly into the city's water treatment plant (infrastructure tour and interview, Marco Antônio Silva Oliveira, SABESP, Santos, Brazil, October 11, 2006). 
13. On hydraulic theories of the state, see Wittfogel 1957 and Ribeiro's review of subsequent literature 1994:14-16.

14. The performative agency of place can make a life and death difference. E.g., when Shakespeare was performed in the border zone between favelas dominated by warring drug gangs in Rio de Janeiro, the fact that a stage was built and violence allayed there, rather than elsewhere, was in itself meaningful, irrespective of the drama onstage (Heritage 2006).

15. Sculptor and architect Maya Lin (2000:1-9), articulating her design impulse in the Montgomery Civil Rights Memorial, captures the same symbolic power at issue in bicas: "I wanted to completely capture the power of water-keeping its flow in careful check so that its energy seems to emanate from within the stone;" or more generally:

I am always trying to find a balance between these opposing forces finding the place where the opposites meet $\sim \sim$ water out of stone $\sim \sim$ glass that flows like water $\sim \sim$ the fluidity of a rock $\sim \sim$ stopping time $\sim \sim$ existing not on either side $\sim \sim$ but on the line that divides $\sim \sim$ and that line takes on a dimensionality it takes on a sense of place and shape.

16. I do not claim that all graffiti is art; I refer specifically to graffiti that bears evidence of its creators' artfulness. On sacred deviance, see Kane 1994.

17. In general, the otherworldly valence of ambivalent heritage is often magnified through association with natural water sources. For Latin American examples of mythical figures associated with streambeds, see Taussig (1997:38) and Kane (2004:74-5, 99-102).

18. These dimensions are commonly missing or obscured in technical and managerial approaches and in scholarship on political ecology and water management.

19. Fixity and flow was the organizing theme for an urban waterfront conference organized by Gene Desfor, Dirk Schubert, and Jennefer Laidley, Hamburg, Germany, on October 10-11, 2008. See Desfor et al., forthcoming.

\section{References Cited}

Bennett, Vivienne, Sonia Dávila-Poblete, and María Nieves Rico, eds.

2005 Opposing Currents: The Politics of Water and Gender in Latin America. Pittsburgh: University of Pittsburgh Press.

Bhabha, Homi

1994 The Location of Culture. London: Routledge.

Bourdieu, Pierre

1998 Practical Reason. Stanford: Stanford University Press.

Braun, Bruce, and Noel Castree

1998 Remaking Reality: Nature at the Millennium. New York: Routledge.

Caldeira, Teresa P.R.

2000 City of Walls: Crime, Segregation, and Citizenship in São Paulo. Berkeley: University of California Press.

Calvino, Italo

1974 Invisible Cities. Trans. William Weaver. New York: Harcourt. 
Caponera, Dante A.

1992 Principles of Water Law and Administration: National and International. Rotterdam: A.A. Balkema.

Chadha, Ashish

2006 "Ambivalent Heritage: Between Affect and Ideology in a Colonial Cemetery." Journal of Material Culture 11/3:339-63.

Chaterjee, Partha

1993 The Nation and Its Fragments. New Jersey: Princeton.

Collins, John.

2008 "But What If I Should Need to Defecate in Your Neighborhood, Madame?': Empire, Redemption, and the 'Tradition of the Oppressed' in a Brazilian World Heritage Site." Cultural Anthropology 23/2:279-328.

Comaroff, John, and Jean Comaroff

1997 Of Revelation and Revolution: The Dialectics of Modernity on a South African Frontier. Chicago: University of Chicago.

Davis, Mike

2006 Planet of Slums. New York: Verso.

Descola, Philippe, and Gísli Pálsson, eds.

1996 Nature and Society: Anthropological Perspectives. New York: Routledge.

Desfor, Gene, Jennefer Laidley, Dirk Schubert, and Quentin Stevens, eds.

Forthcoming Changing Urban Waterfronts. New York: Routledge Press.

Douglas, Mary

1966 Purity and Danger: An Analysis of Concepts of Pollution and Taboo. Boston: Routledge and Kegan Paul.

Ferrell, Jeff.

1993 Crimes of Style: Urban Graffiti and the Politics of Criminality. Boston: Northeastern University Press.

2001 Tearing Down the Streets: Adventures in Urban Anarchy. New York: Palgrave.

Fortun, Kim, and Mike Fortun, eds.

2007 "The Coke Complex." SPECIAL ESSAY CLUSTER, Cultural Anthropology 22/4: 616-84.

Forty, Adrian

1992 Objects of Desire: Desire and Society since 1750. London: Thames and Hudson.

Gell, Alfred

1998 Art and Agency: An Anthropological Theory. Oxford: Clarendon Press.

Haberman, David L.

2006 River of Love in an Age of Pollution: The Yamuna River of Northern India. Berkeley: University of California Press.

Heritage, Paul

2006 "Parallel Power: Shakespeare, Gunfire, and Silence." In Performance and Place, ed. Leslie Hill and Helen Paris, 192-206. New York: Palgrave Macmillan.

Kaika, Maria

2005 City of Flows: Modernity, Nature, and the City. New York: Routledge. 
Kane, Stephanie

1994 "Sacred Deviance and AIDS in a North American Buddhist Community." Law and Policy 16/3:323-39.

2004 The Phantom Gringo Boat: Shamanic Discourse and Development in Panama, 2nd ed. Christchurch, New Zealand: Cybereditions. www.cybereditions. com.

2008 “The Poisoned Waters of Conceiçãozinha." Anthropology News 49/5:31. www.flickr.com/photos/anthropologynews/sets/72157604772920122/ www.aaanet.org/publications/articles.cfm.

2009 "Stencil Graffiti in Urban Waterscapes of Argentina (Buenos Aires \& Rosario)." Crime Media Culture 5/1: 9-28.

Lefebvre, Henri

1991 The Production of Space, trans. Donald Nicholson-Smith. Oxford: Basil Blackwell.

Lévi-Strauss, Claude.

1967 Structural Anthropology. New York: Doubleday.

Lima, Renilda Fátima Gonçalves de.

2005 Caracterização Hidrogeológica e Ambiental das Fontes de Águas Naturais da Cidade Alta de Salvador. Graduation thesis. Geoscience Institute, Department of Geology and Applied Geophysics. Universidade Federal da Bahia.

Limbert, Mandana E.

2001 “The Senses of Water in an Omani Town.” Social Text 19/3:35-55.

Lin, Maya.

2000 Boundaries. New York: Simon and Schuster.

Meinzen-Dick, Ruth, and Rajendra Pradhan

2005 "Analyzing Water Rights, Multiple Uses, and Intersectoral Water Transfers." In Liquid Relations: Contested Water Rights and Legal Complexity, ed. Rutgerd Boelens, Dik Roth, and Margreet Zwarteveen, 237-53. New Brunswick: Rutgers.

Ribeiro, Gustavo Lins

1994 Transnational Capitalism and Hydropolitics in Argentina: The Yacyretá High Dam. Gainesville: University of Florida Press.

Sassen, Saskia

2006 Territory-Authority-Rights: From Medieval to Global Assemblages. Princeton: Princeton University Press.

Schacter, Rafael

2008 "An Ethnography of Iconoclash: An Investigation into the Production, Consumption and Destruction of Street-Art in London." Journal of Material Culture 13/1:35-61.

Strang, Veronica

2004 The Meaning of Water. New York: Berg.

Swyngedouw, Erik

2004 Social Power and the Urbanization of Water: Flows of Power. New York: Oxford University Press.

Taussig, Michael

1997 The Magic of the State. New York: Routledge. 
Taylor, Diana

2003 The Archive and the Repertoire: Performing Cultural Memory in the Americas. Durham: Duke.

Teixeira, Manoel Neto

2004 Olinda: Das Colinas à Planície. Funcultura Pernambuco, Fundo Pernamubuco de Incentivo a Cultura. Governo do Estado: Secretaria de Educação e Cultura.

UNESCO

2008 "Historic Centre of the Town of Olinda." World Heritage. http://whc. unesco.org/en/list/189.

Wittfogel, Karl A.

1957 Oriental Despotism: A Comparative Study of Total Power. New Haven: Yale University Press.

Young, Alison

2005 Judging the Image: Art, Value, Law. London: Routledge.

Zukin, Sharon

1991 Landscapes of Power: From Detroit to Disney World. Berkeley: University of California Press.

STEPHANIE C. Kane, a cultural anthropologist and ecologist by training, has a passion for folklore. Kane authored The Phantom Gringo Boat (1994/2004), AIDS Alibis (1998), and co-edited Crime's Power (2003). Recent essays on art, environment, and justice issues appear in Signs (2007) and Crime Media Culture (2009). Kane is an associate professor in the Department of Criminal Justice at Indiana University and an affiliate faculty in the Department of Folklore and Ethnomusicology. (stkane@indiana.edu) (www.indiana.edu/ culturex) 